\title{
Highlight report: perspectives in stem cell research-unbiased quantification of the similarity between in vitro generated and primary hepatocytes
}

\author{
Ahmed Ghallab ${ }^{1}$
}

Received: 7 September 2015 / Accepted: 8 September 2015 / Published online: 26 September 2015

(C) Springer-Verlag Berlin Heidelberg 2015

In vitro systems represent a cutting-edge topic in toxicology (Grinberg et al. 2014; Frey et al. 2014; Godoy et al. 2013; Godoy 2011; Stewart and Marchan 2014). Particularly, in the fields of liver (Godoy et al. 2013; Zellmer et al. 2010; Godoy and Bolt 2012), kidney (Faiz et al. 2015; Yang et al. 2014), and neurotoxicity (Zimmer et al. 2014; Waldmann et al. 2014; Krug et al. 2013), in vitro systems are frequently used. Primary human cells still represent a gold standard in toxicological research (Heise et al. 2012; Ghallab 2013, 2014a, b). However, their use is hampered by difficult availability (Hewitt et al. 2007; Hengstler et al. 2000).

Theoretically, stem cells offer a possibility to overcome this limitation. However, it is discussed controversially to which degree stem cell-derived cells resemble primary cells. In the field of stem cell-derived hepatocyte-like cells, some authors reported that generation of 'functional,' 'high fidelity' hepatocytes from stem and precursor cells is already possible (Medine et al. 2013; Szkolnicka et al. 2014; Huang et al. 2014), while others present a more critical point of view (Morris et al. 2014; Hengstler et al. 2005; Brulport et al. 2007).

In this controversial situation, it is helpful that Godoy et al. (2015) have recently published a technique how the cellular nature of stem cell-derived hepatocytes can be quantitatively determined in an unbiased manner. The authors studied hepatocyte-like cells that have been differentiated from human embryonic stem cells as well as induced pluripotent stem cells in three different research

Ahmed Ghallab

Ghallab@vet.svu.edu.eg

1 Forensic Medicine and Toxicology Department, Faculty of Veterinary Medicine, South Valley University, Qena, Egypt centers. Genome-wide expression analysis was performed to be able to determine the nature of the stem cell-derived cells in an unbiased manner. The authors used CellNet, a recently established software to quantify the similarity of the stem cell-derived cells with human cell types, such as hepatocytes, colon, and kidney cells (Cahan et al. 2014; Morris et al. 2014). The results obtained with the genomewide data of the cells from all three research centers were remarkably similar, although each center used an independently optimized differentiation protocol. As expected, the score for embryonic stem cells strongly decreased, while the score for hepatocytes strongly increased but not to values of 1.0, the result of primary human hepatocytes but to (depending on the different protocols) values ranging between 0.5 and 0.6 . Therefore, the stem cell-derived cells covered only a bit more than half of the 'distance' between stem cells and real human hepatocytes. One reason for incomplete differentiation is a cluster of genes representing mature liver functions that are expressed at too low values. This 'unsuccessful cluster' is controlled by the transcription factors HNF1, CAR, FXR, and PXR, showing too low activities in the stem cell-derived hepatocytes. Genomewide analysis of gene regulatory networks also revealed two 'unwanted' features of the stem cell-derived hepatocyte-like cells. The scores of colon- as well as fibroblastassociated genes clearly increased. The study of Godoy and colleagues leads to some generally relevant key messages for the stem cell community:

- Characterizing stem cell-derived cells by a limited number of selected markers is no longer state of the art. The risk of a bias and misleading conclusions is high.

- Today, genome-wide analyses, either by RNAseq or gene array, are fast and relatively cheap. They allow an unbiased analysis, and the nature of the analyzed cells 
can be quantitatively described. This also allows identification of unwanted features, such as induction of colon genes. Moreover, transcription factors responsible for 'unwanted side effects' of current hepatocyte differentiation protocols will be identified. Although numerous studies about hepatocyte differentiation have been published, the feature of unwanted colon differentiation remained unnoticed until recently. Software for analysis of genome-wide data, such as CellNet, or clustering as well as overrepresentation analysis tools is free and publicly available, further facilitating the application of unbiased genome-wide techniques.

\section{References}

Brulport M, Schormann W, Bauer A, Hermes M, Elsner C, Hammersen FJ, Beerheide W, Spitkovsky D, Härtig W, Nussler A, Horn LC, Edelmann J, Pelz-Ackermann O, Petersen J, Kamprad M, von Mach M, Lupp A, Zulewski H, Hengstler JG (2007) Fate of extrahepatic human stem and precursor cells after transplantation into mouse livers. Hepatology 46(3):861-870. doi:10.1002/ hep. 21745

Cahan P, Morris SA, Collins JJ, Daley GQ (2014) Defining cellular identity through network biology. Cell Cycle 13(21):3313-3314. doi:10.4161/15384101.2014.972918

Faiz H, Boghossian M, Martin G, Baverel G, Ferrier B, ConjardDuplany A (2015) Cadmium chloride inhibits lactate gluconeogenesis in mouse renal proximal tubules: an in vitro metabolomic approach with ${ }^{13} \mathrm{C}$ NMR. Toxicol Lett 238(3):45-52. doi:10.1016/j.toxlet.2015.07.018

Frey O, Misun PM, Fluri DA, Hengstler JG, Hierlemann A (2014) Reconfigurable microfluidic hanging drop network for multi-tissue interaction and analysis. Nat Commun 5:4250. doi:10.1038/ ncomms 5250

Ghallab A (2013) In vitro test systems and their limitations. EXCLI J $12: 1024-1026$

Ghallab A (2014a) Human non-parenchymal liver cells for co-cultivation systems. EXCLI J 13:1295-1296

Ghallab A (2014b) The rediscovery of HepG2 cells for prediction of drug induced liver injury (DILI). EXCLI J 13:1286-1288

Godoy P (2011) Hepatotoxicity. EXCLI J 10:124-127

Godoy P, Bolt HM (2012) Toxicogenomic-based approaches predicting liver toxicity in vitro. Arch Toxicol 86(8):1163-1164. doi:10.1007/s00204-012-0892-5

Godoy P, Hewitt NJ, Albrecht U et al (2013) Recent advances in 2D and $3 \mathrm{D}$ in vitro systems using primary hepatocytes, alternative hepatocyte sources and non-parenchymal liver cells and their use in investigating mechanisms of hepatotoxicity, cell signaling and ADME. Arch Toxicol 87(8):1315-1530. doi:10.1007/ s00204-013-1078-5

Godoy P, Schmidt-Heck W, Natarajan K, Lucendo-Villarin B, Szkolnicka D, Asplund A, Bjorquist P, Widera A, Stoeber R, Campos G, Hammad S, Sachinidis A, Damm G, Weiss TS, Nussler A, Synnergren J, Edlund K, Küppers-Munther B, Hay D, Hengstler JG (2015) Gene networks and transcription factor motifs defining the differentiation of stem cells into hepatocyte-like cells. J Hepatol. doi:10.1016/j.jhep.2015.05.013

Grinberg M, Stöber RM, Edlund K, Rempel E, Godoy P, Reif R, Widera A, Madjar K, Schmidt-Heck W, Marchan R, Sachinidis A, Spitkovsky D, Hescheler J, Carmo H, Arbo MD, van de Water B, Wink S, Vinken M, Rogiers V, Escher S, Hardy B, Mitic D,
Myatt G, Waldmann T, Mardinoglu A, Damm G, Seehofer D, Nüssler A, Weiss TS, Oberemm A, Lampen A, Schaap MM, Luijten M, van Steeg H, Thasler WE, Kleinjans JC, Stierum RH, Leist M, Rahnenführer J, Hengstler JG (2014) Toxicogenomics directory of chemically exposed human hepatocytes. Arch Toxicol 88(12):2261-2287. doi:10.1007/s00204-014-1400-x

Heise T, Schug M, Storm D, Ellinger-Ziegelbauer H, Ahr HJ, Hellwig B, Rahnenfuhrer J, Ghallab A, Guenther G, Sisnaiske J, Reif R, Godoy P, Mielke H, Gundert-Remy U, Lampen A, Oberemm A, Hengstler JG (2012) In vitro-in vivo correlation of gene expression alterations induced by liver carcinogens. Curr Med Chem 19(11):1721-1730. doi:10.2174/092986712799945049

Hengstler JG, Utesch D, Steinberg P, Platt KL, Diener B, Ringel M, Swales N, Fischer T, Biefang K, Gerl M, Böttger T, Oesch F (2000) Cryopreserved primary hepatocytes as a constantly available in vitro model for the evaluation of human and animal drug metabolism and enzyme induction. Drug Metab Rev 32(1):81118. doi:10.1081/DMR-100100564

Hengstler JG, Brulport M, Schormann W, Bauer A, Hermes M, Nussler AK, Fandrich F, Ruhnke M, Ungefroren H, Griffin L, Bockamp E, Oesch F, von Mach MA (2005) Generation of human hepatocytes by stem cell technology: definition of the hepatocyte. Expert Opin Drug Metab Toxicol 1(1):61-74. doi:10.1517/17425255.1.1.61

Hewitt NJ, Lechón MJ, Houston JB, Hallifax D, Brown HS, Maurel P, Kenna JG, Gustavsson L, Lohmann C, Skonberg C, Guillouzo A, Tuschl G, Li AP, LeCluyse E, Groothuis GM, Hengstler JG (2007) Primary hepatocytes: current understanding of the regulation of metabolic enzymes and transporter proteins, and pharmaceutical practice for the use of hepatocytes in metabolism, enzyme induction, transporter, clearance, and hepatotoxicity studies. Drug Metab Rev 39(1):159-234. doi:10.1080/03602530601093489

Huang PY, Zhang LD, Gao YM, He ZY, Yao D, Wu ZT et al (2014) Direct reprogramming of human fibroblasts to functional and expandable hepatocytes. Cell Stem Cell 14:370-384. doi:10.1016/j.stem.2014.01.003

Krug AK, Kolde R, Gaspar JA, Rempel E, Balmer NV, Meganathan K, Vojnits K, Baquié M, Waldmann T, Ensenat-Waser R, Jagtap S, Evans RM, Julien S, Peterson H, Zagoura D, Kadereit S, Gerhard D, Sotiriadou I, Heke M, Natarajan K, Henry M, Winkler J, Marchan R, Stoppini L, Bosgra S, Westerhout J, Verwei M, Vilo J, Kortenkamp A, Hescheler J, Hothorn L, Bremer S, van Thriel C, Krause KH, Hengstler JG, Rahnenführer J, Leist M, Sachinidis A (2013) Human embryonic stem cell-derived test systems for developmental neurotoxicity: a transcriptomics approach. Arch Toxicol 87(1):123-143. doi:10.1007/s00204-012-0967-3

Medine CN, Lucendo-Villarin B, Storck C, Wang F, Szkolnicka D, Khan F et al (2013) Developing high-fidelity hepatotoxicity models from pluripotent stem cells. Stem Cells Transl Med 2:505-509. doi:10.5966/sctm.2012-0138

Morris SA, Cahan P, Li H, Zhao AM, San Roman AK, Shivdasani RA et al (2014) Dissecting engineered cell types and enhancing cell fate conversion via CellNet. Cell 158:889-902. doi:10.1016/j. cell.2014.07.021

Stewart JD, Marchan R (2014) Current developments in toxicology. EXCLI J 11:692-702

Szkolnicka D, Farnworth SL, Lucendo-Villarin B, Hay DC (2014) Deriving functional hepatocytes from pluripotent stem cells. Curr Protoc Stem Cell Biol 30:1G.5.1-1G.5.12. doi:10.1002/9780470151808.sc01g05s30

Waldmann T, Rempel E, Balmer NV, König A, Kolde R, Gaspar JA, Henry M, Hescheler J, Sachinidis A, Rahnenführer J, Hengstler JG, Leist M (2014) Design principles of concentration-dependent transcriptome deviations in drug-exposed differentiating stem cells. Chem Res Toxicol 27(3):408-420. doi:10.1021/tx400402j 
Yang Y, Liu H, Liu F, Dong Z (2014) Mitochondrial dysregulation and protection in cisplatin nephrotoxicity. Arch Toxicol 88(6):12491256. doi:10.1007/s00204-014-1239-1

Zellmer S, Schmidt-Heck W, Godoy P, Weng H, Meyer C, Lehmann T, Sparna T, Schormann W, Hammad S, Kreutz C, Timmer J, von Weizsäcker F, Thürmann PA, Merfort I, Guthke R, Dooley S, Hengstler JG, Gebhardt R (2010) Transcription factors ETF, E2F, and SP-1 are involved in cytokine-independent proliferation of murine hepatocytes. Hepatology 52(6):2127-2136. doi:10.1002/ hep. 23930

Zimmer B, Pallocca G, Dreser N, Foerster S, Waldmann T, Westerhout J, Julien S, Krause KH, van Thriel C, Hengstler JG, Sachinidis A, Bosgra S, Leist M (2014) Profiling of drugs and environmental chemicals for functional impairment of neural crest migration in a novel stem cell-based test battery. Arch Toxicol 88(5):1109-1126. doi:10.1007/s00204-014-1231-9 